\title{
顎関節損傷が澦の機能と成長発育に及ぼす影響に関する実験的研究
}

\author{
山田隆造
}

\section{An experimental study on the function, growth and development of jaw influenced by temporo-mandibular joint destruction}

\author{
Ryuzo YAMADA
}

緒

\section{言}

交通事故, 災害事故の増加に伴い, 顎顔面外傷の増加 は著しく, 下顎骨の解剖学的弱点の一つである顎関節に 損傷が及ぶ機会も増加している。顎関節に損傷が及んだ 場合, 著しい顎の機能障害が発生するが，その患者が小

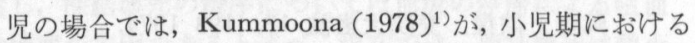
顎関節に対する損傷は, その原因の70\%が外傷であり, 顎関節強直症へと連なり，顎顔面の成長発育が著しく障 害されると報告しているよらに，機能障害のほかに顎顔 面の成長発育も著しく障害される.

しかし，顎関節損傷後の顎関節部の治癒過程に関する 研究 ${ }^{2)}$, 下顎頭切除後の顎の成長発育や変形についての 研究 ${ }^{329)}$ は行われているが，顎関節損傷後の顎の成長発 育に関する研究は全くみられない.

そこで著者は, 人と解剖学的構造が類似する成長期の カニクイ猿の顎関節に損傷を与え, 顎の機能的変化, 顎 関節部の変化拈よび顎の成長発育の变化を追求する目的 で本研究を行った.

\section{実験材料，実験方法ならびに観察方法}

\section{1. 実験動物}

体重 $0.9 \sim 2.2 \mathrm{~kg}$ の乳歯列完成期 $\left(\frac{\text { i i c m m }}{\text { i i c m m }}\right)$ から第 1 大臼歯萌出期 $\left(\frac{\text { i i c m m M }}{\text { i i m m M }}\right)$ までの Macacus Irus Monkey 14 匹を用いた.これらの動物は Bowen ら $(1970)^{10)}$ の歯牙年歯より生後 $7 \sim 16 \mathrm{M}$ と推定される.

\section{2. 実験方法}

実験動物を両側性顎関節損傷群（以下 B-TMJ 群と略 す） 6 匹，片側性顎関節損傷群（以下 U-TMJ 群と略

す） 4 匹および対照群（以下 C-TMJ 群と略す） 4 匹に

大阪歯科大学口腔外科学教室第 1 講座（指導: 高須 淳教授)

The First Department of Oral Surgery, Osaka Dental University (Director: Prof. Jun Takasu) 受付日：昭和55年 8 月 11 日
分けて実験に供した。ネンブタール腹腔内注射による全 身麻酔下に, 口内より $\overline{\mathrm{A} \mid \mathrm{A}}$ 正中部 (図 1) と| $\overline{\mathrm{E}}$ 根尖遠 心部に, 口外より咬筋を傷つけないように左下顎角部 に，それぞれ0.8 mm サンュパルトクラスプ線（三金工 業株式会社製) $0.8 \times 0.8 \times 0.8 \mathrm{~mm}$ の metal implant を 行った。 2 週間創部の治癒を待った後, 再びネンブター ル麻酔下に, 左側耳前切開を行い, 皮虞, 皮下組織拈よ び筋膜を剝離し，左側下顎頭に前述のサンコパルトクラ スプ線の metal implantを行った. その際, U-TMJ 群と B-TMJ 群では, 今上 $(1977)^{2)}$ の方法に従って関 節円板を切除し，下顎頭と関節窩の軟骨層を歯科用ラウ ント゚パー（4 番）で，できるだけ軟骨を残さないよらに 広範囲に挫減損傷した（図 2 )。術後，創腔を抗生物質 溶液で洗浄し，耳下腺咬筋筋膜を腸線で縫合して顎関節 部を閉鎖した後，皮膚縫合を行った。なお，B-TMJ 群 では上記と同じ操作で右顎関節部の損傷をも行った。施 術後は感染防止の目的で, AB-PC $30 \mathrm{mg} / \mathrm{kg} /$ day の筋 肉内注射を 3 日間行った.

実験開始から終了まで，サル用固型飼料（オリエンタ ル酵母工業株式会社製) のほかに，開口訓練の目的でリ ンゴやナシを大きな食片のまま与えた。

実験開始24か月後, 実験動物の左右総頸動脈を剖出, 切断して脱血死させ, 中心咬合位の状態で左右総頸動脈 より $70 \%$ ルコールを $200 \mathrm{ml}$ 注入し, 灌流固定後, 機

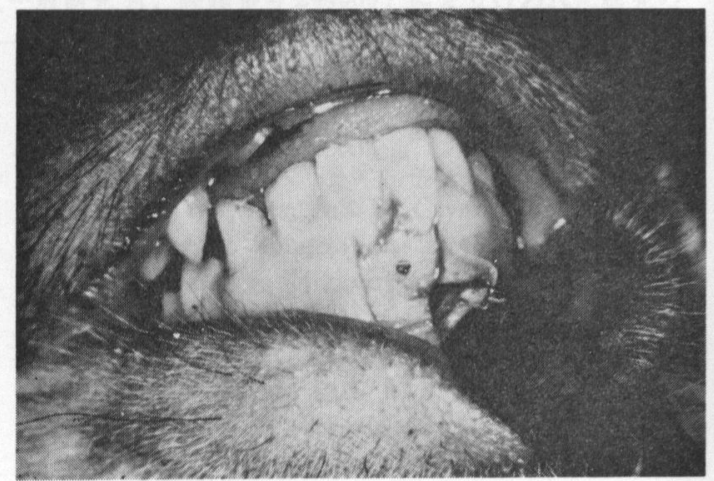

図 1 手術術式 metal implant 


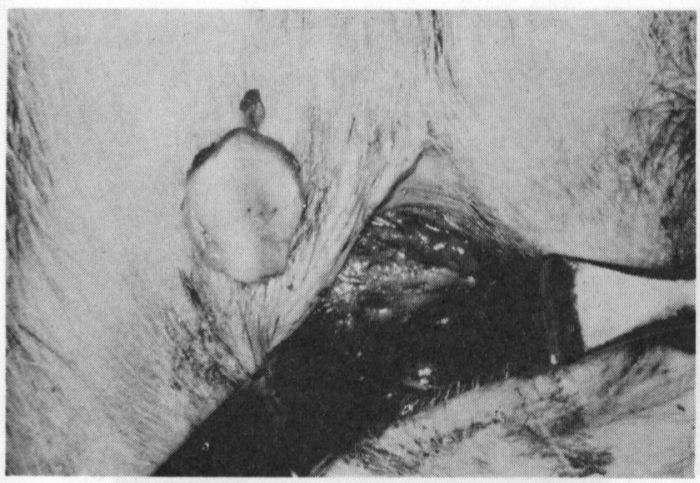

図 2 手術術式 顎関節損傷

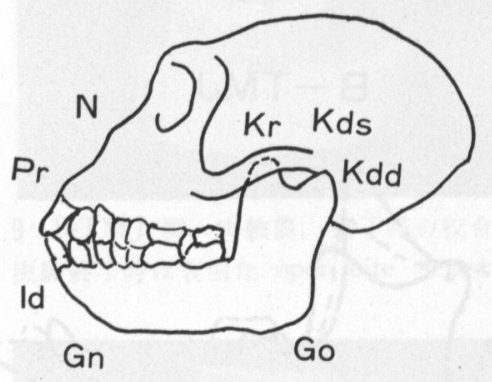

1. 顔面高 $\mathrm{N} \sim \mathrm{Gn}$

2. 上顔面高 $\mathrm{N} \sim \mathrm{Pr}$

3. オトガイ高 $\mathrm{ld} \sim \mathrm{Gn}$

4. 眼窩下縁 上顎米頸部

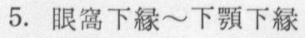

6. 頓骨弓上縁〜下顎下緣

7. 下顎長 $1 d \sim K d d$

8. 下顎体長 $l d \sim$ Go

9. 下顎枝角

10. 下顎体高（オトガイ孔部）

11. 下顎体高 (Mi 部)

12. 下顎枝垂直高

13. 筋突起高

14. 下顎枝高 $\mathrm{Kds} \sim \mathrm{Go}$

15. 筋突起 $\sim \mathrm{Go} \mathrm{Kr} \sim \mathrm{Go}$

16. 下顎最小枝幅

17. 筋 - 関節突起線の傾斜角

図 3 計測点々計測項目

械的に軟組織を除去し，頭蓋（以下摘出骨と略す）を摘 出した。

\section{3. 観察方法}

1) 機能的観察

術前, 術後は, 2 週, 4 週, 6 週, 8 週, 3 か月, 4 か月， 5 か月， 6 か月， 12 か月， 18 か月および 24 か月 (実験終了時) に, ネンブタール全身麻酔下に, 下顎切歯 部を $200 \mathrm{~g}$ の力で下方向に轶引して開口させ, その時の 開口距離（上下中切歯切端間距離-open bite 值) を測定 した。またその際，open bite，閉口時の下顎正中線の ずれおよび側方運動制限の有無を観察した.

2）頭部X線規格写真による観察

metal implant 完了直後，12か月後および実験終了時 の 3 回, Fuji X-ray film ( 6 切) を用いて, 左側頭部 X 線規格写真撮影を行った。 また，骨縫合のない同一骨内 では, 各implant 間の距離は不変であることから，各セ ファロ写真を implant 点で重ね合わせ, 各時点での下 顎骨の外形を同一のトレーシングペーパー上にトレース して, 経時的な下顎骨の成長発育の変化を観察した.

3）咬合状態の観察

実験動物の実験前の咬合状態の異常の有無の確認と, 実験終了時との比較の目的で, 実験前と実験終了時に上 下顎の印象を採得，模型を作成し，咬合状態を観察し た.

4 ) 摘出骨の肉眼的観察と各部の計測

摘出骨の肉眼的観察を行った. また同時に, Martin $(1957)^{12)}$ ，上條 $(1965)^{13)}$ 执よび Sorensen ら(1975) ${ }^{8)}$ に

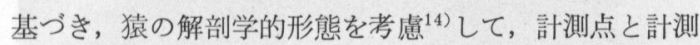
項目17 を規定し (図 3), 摘出骨の各部を計測した後, 動物の大きさを同一の scale にあわせる目的で，各動物 の左下顎体長を 100 として，それぞれの計測值をあらわ し，5\%の危険率で各群間の各計測項目について有意差 検定を行った.

\section{5 ) 顎関節部のX線的観察}

屠殺した全動物の左，右の顎関節部を，距離 $20 \mathrm{~cm}$, 管電圧 $42.5 \mathrm{KVp}$, 管電流 $12 \mathrm{~mA}$ ，照射時間 $0.3 \sim 0.5$ 秒 で, 今上 $(1977)^{15)}$ の方法に従って撮影し, 観察した.

6) テトラサイクリン（以下 TC と略す）生体時刻描 記による下顎骨各部の研磨標本の観察

metal implant 完了直後, 6 か月後, 12 か月後, 18 か 月後の 4 回, 骨の成長を障害しないで明瞭なる成長線を 出すため ${ }^{16)} に$, 静注用 oxytetracycline $30 \mathrm{mg} / \mathrm{kg}$ の腹 腔内注射を行った。

24 か月後, 屠殺した各群の半数の動物の下㖽骨正中 部, $\overline{6}|,| \overline{6}$ 部, 左, 右下顎枝部, 左, 右顎関節部を 摘出し, 脱水,リゴラック包埋 (Rigolac $70 \mathrm{~F}$ : Rigolac $2004=2: 8$ ) 後, 各部の $30 \mu \mathrm{m}$ の研磨標本を作成し, 親里 $(1972)^{17)}$ の方法に従って, Olympus 超高圧水銀照 明装置 HLS-II を使用し, 1 次フィルターにDV-I を 用いて 300 400 nm の波長の紫外線を求め, 2 次>1 ルターに Kodak Wratten Gelatin Filter No. 2 C 扰よ び No. 6 を用いて暗視野照明下に標本を観察し, Kodak High Speed Ektachrome Color Film (ASA 200) を使 用し, 露出時間は20秒から 4 分で写真撮影を行った。

7 ) 顎関節部の組織学的観察

研磨標本作成に用いた以外の各群の半数の動物の顎関 節部を，1 週間 10\%中性ホルマリンで再固定後, Morse 法(1945) ${ }^{18)}$ にて脱灰し，セロイジン・パラフィン包埋を 


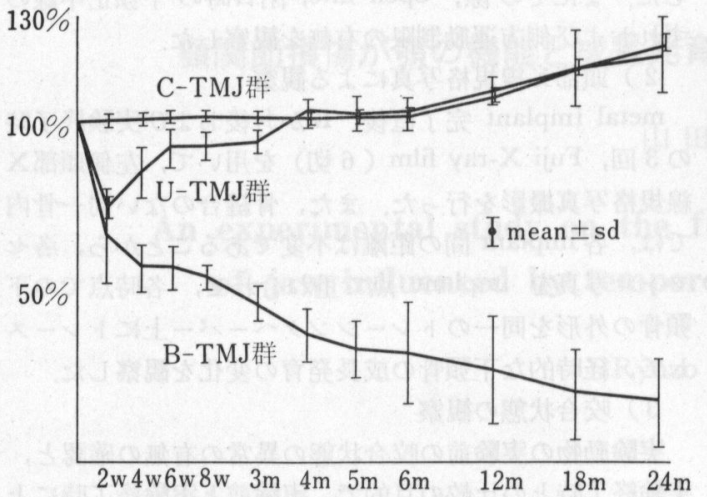

図 4 開口距離の経日的変化

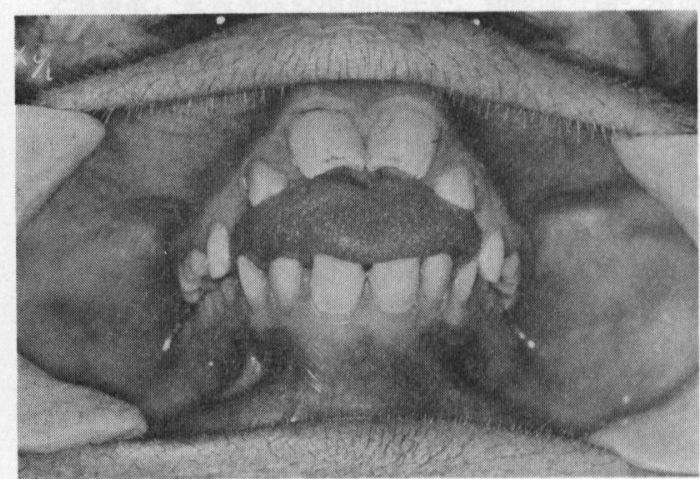

図 5 B-TMJ 群 2 年経過時の咬合状態 著明な open biteがみられる。

行い, 矢状方向に $10 \mu \mathrm{m}$ の連続切片にし, HematoxylinEosin 重染色执よぴ Azan 染色を行い鏡検した.

\section{実 験 成 績}

\section{1. 機能的観察}

䫇関節の可動性の指標として, 開口距離を測定し，術 前值を $100 \%$ とする百分率で表した（図 4).B-TMJ 群 では，開口距離は実験開始後徐々に低下しはじめ，6 か 月経過時で術前の約30\%，1 年経過時で約 $25 \% ， 2$ 年経 過時では約20\%にまで減少した。また 6 匹の実験動物の 万ち 2 匹は実験開始 1 年経過時に開口不能 となった。

U-TMJ 群では, $2 \sim 4$ 週経過時, 開口距離は術前の約 $80 \%$ に低下したが，4 か月経過時には術前值に復し，以 後増大し， 2 年経過時には約 $115 \%$ を示した。 C-TMJ 群は, 徐々に開口距離は增大し， 2 年経過時には術前の 約 120\%を示した, open bite は, B-TMJ 群の 6 匹の らち 4 匹にみられ，実験開始 1 年経過時にあらわれはじ め, 徐々に増大し, 最高 $9 \mathrm{~mm}$ を示した（図 5 )。また

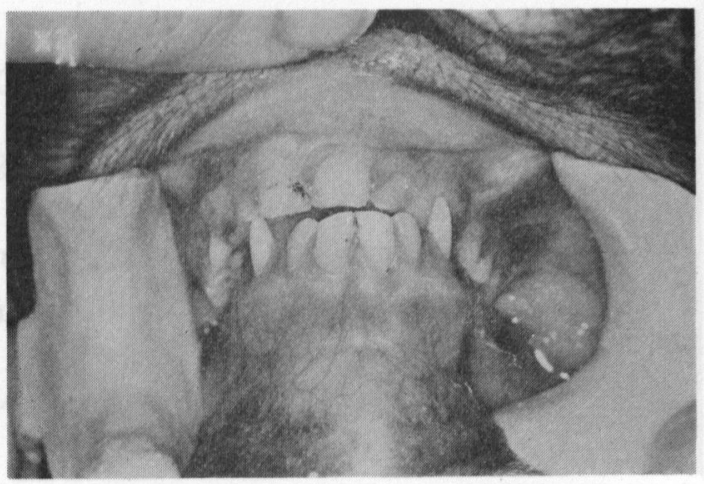

図 6 U-TMJ 群 2 年経過時の咬合状態 著明な下顎正中の実験側への変位がみられる。

\section{B-TMJ}

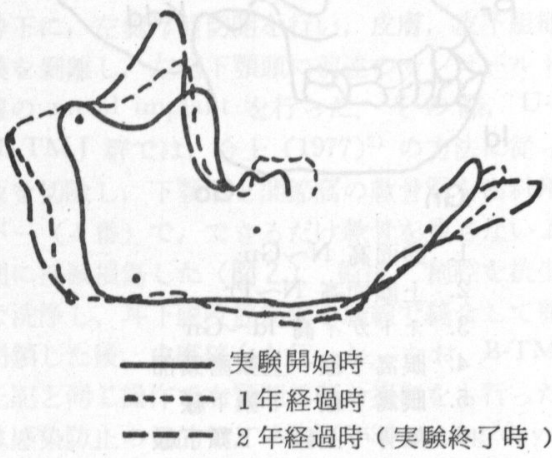

図 7 B-TMJ 群で開口不能となった動物の頭 部X線規格写真による下顎骨の成長発育 の変化

下顎頭の成長停止と下顎前歯部唇側の骨吸収が みられる。

\section{C-TMJ}

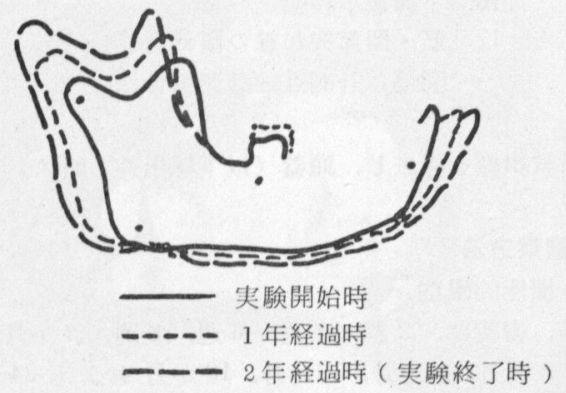

図 8 C-TMJ 群の動物の頭部X線規格写真に よる下顎骨の成長発育の変化 正常な成長発育を示す。 


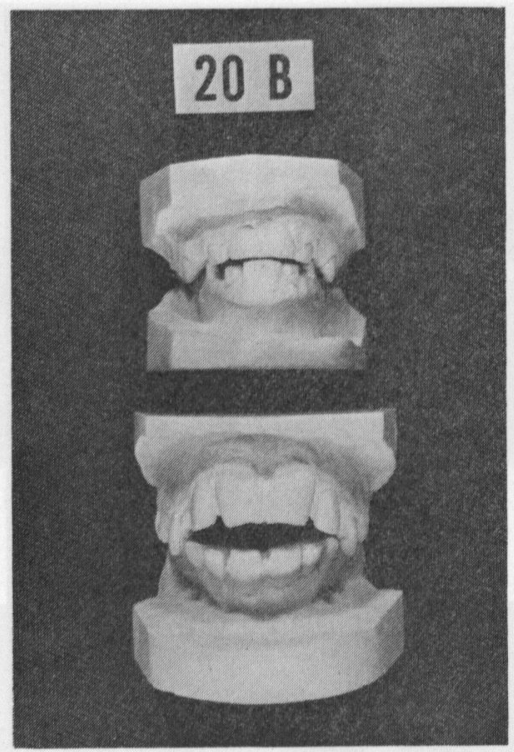

図 9 B-TMJ 群 実験前, 終了時の咬合状態 実験終了時は著明な open biteを示す。

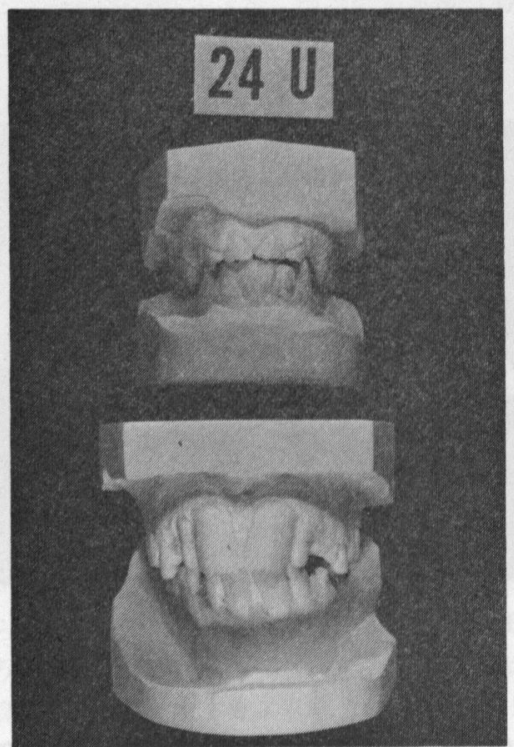

図 $10 \mathrm{U}-\mathrm{TMJ}$ 群 実験前, 終了時の咬合状態 実験終了時は著明な下顎正中の実験側への変位を示 す.

これは，開口距離の少ない動物はど著明にみられた。

側方運動制限は，B-TMJ 群では両側性に著明にみら れ，開口不能の動物では全く側方運動ができなかった。 U-TMJ 群では; 右側 (非実験側) への運動制限がみら れた，閉口時の下顎正中の左側 (実験側) へのずれは， U-TMJ 群に 6 か月経過時よりあらわれはじめ, 全実験

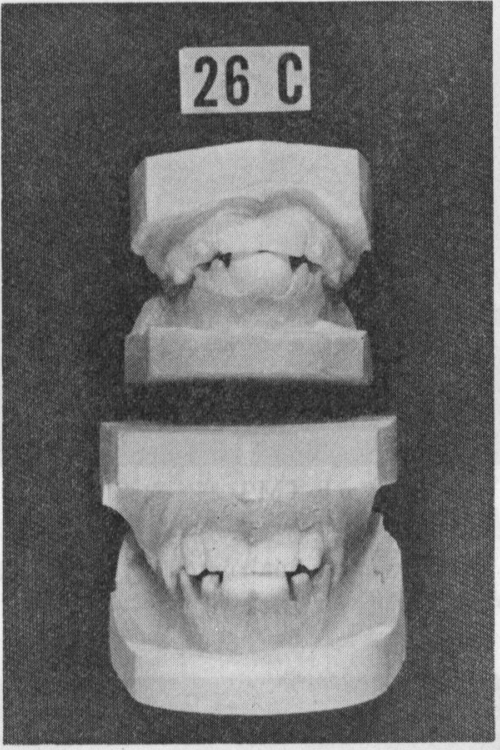

図 $11 \mathrm{C}-\mathrm{TMJ}$ 群 実験前, 終了時の咬合状態 実験前，終了時とも正常な咬合状態を示す。

期間を通じて徐々に増大し，最高 $2.4 \mathrm{~mm}$ を示した（図 6). C-TMJ 群では open bite，側方運動制限および下 顎正中のずれはみられなかった。

\section{2. 頭部 $\mathbf{X}$ 線規格写真による観察}

B-TMJ 群では，下顎頭の伸長はみられず，筇突起が 異常に伸長したため, 下顎切痕が消失したいびつな形態 を示し，下顎枝部は，後縁の骨添加と前縁の骨吸収がみ られた。

下顎体部は，下顎下縁の骨添加がみられ，antegonial notch が著明にみられるようになった.

下顎前歯部は，開口が保たれている4 匹の動物に唇側 の骨添加がみられたが，開口不能となった 2 匹の動物で は唇側の骨吸収がみられた（図７）.

C-TMJ 群では，下顎頭，筋突起の後上方への伸長が みられ，下顎切痕が著明となり，下顎枝部は，後縁の骨 添加と前縁の骨吸収がみられた。

下顎体部は，下顎下縁と前歯部唇側への骨添加がみら れた. antegonial notch も徐々にあらわれてきたが， B-TMJ 群よりその程度は少なかった（図 8）.

U-TMJ 群では, 左右の発育状態がいびつであり, 頭部X線規格写真上での明確な追跡は困難であるが， C-TMJ 群と同様に，下顎枝後縁，下顎下緣，下顎前歯 部唇側および筋突起の骨添加と下顎枝前縁の骨吸収がみ られたが，実験側の下顎頭部の伸長はみられなかった。

\section{3. 咬合状態の観察}

実験に用いた14匹いずれの動物も，実験前の咬合状態 は正常であった.

実験終了時では，B-TMJ 群は，6 匹中 4 匹が著明な 


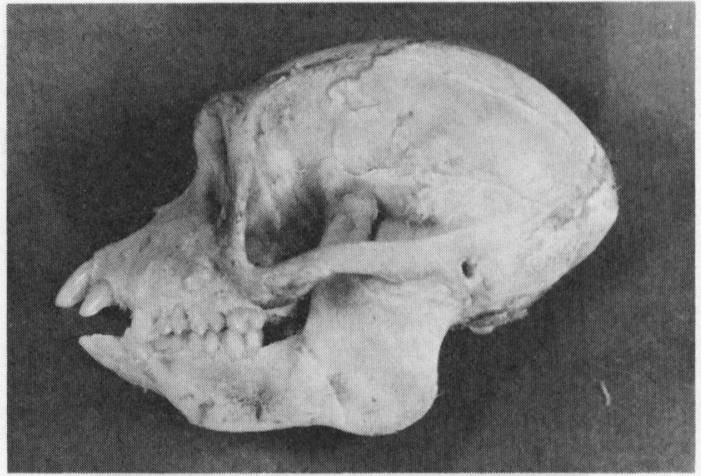

図 12 B-TMJ 群 肉眼所見

下顎頭の成長停止, 筋突起の伸長, 下顎枝角の鋭角 度化. 著明な antegonial notch, open bite および 煩骨弓の平坦化がみれる。

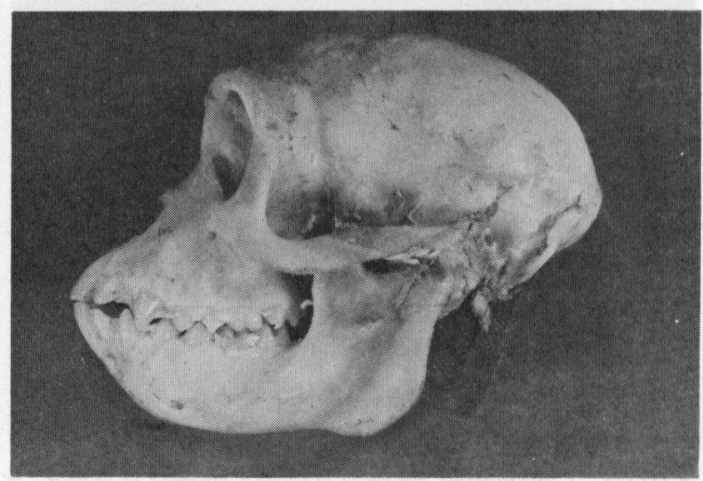

図 13 C-TMJ 群 肉眼所見 正常な側面像を示す.

open bite を示し，臼歯部で咬合した（図 9）。U-TMJ 群は,すべての動物とも下顎正中部が損傷顎関節側へ変 位し， 曰歯部は損傷顎関節側で咬合した（図 10）。CTMJ 群はすぺて正常な咬合状態であった（図 11）.

\section{4. 摘出骨の肉眼的観察と各部の計測}

a) 肉眼的観察

B-TMJ 群（図12）は，C-TMJ 群（図13）と比ぺる と，下顎枝部と前歯部に大きな形態の変化がみられた。 すなわち，下顎枝部では筋突起が煩骨弓を越え，後上方 への伸長がみられたが，それに反して，下顎頭の成長は 停止し，下顎切痕がほとんど消失した，また，下顎枝角 が鋭角度化し, antegonial notch が強調された。開口 不能に陥った 2 匹の動物では，舌側面へのたな状の骨添 加がみられた（図 14）。このような下顎骨の変化につれ て，上顎部にも変化が及び，頓骨弓が平坦となり，上顎 部の垂直高の成長が著しく阻害されているのがみられ た.

U-TMJ 群の実験側（図15）でも，筋突起の煩骨弓を

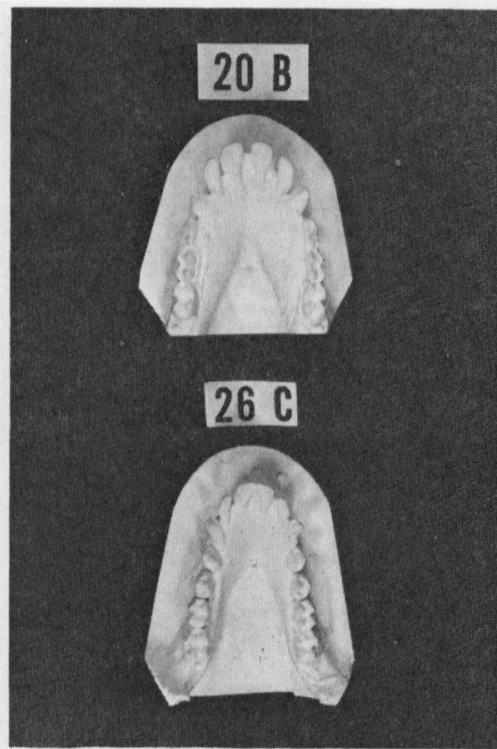

図 14 B-TMJ 群，C-TMJ 群，実験終了時 の下顎骨舌側面像（摘出した下顎骨の 印象模型)

B-TMJ 群では, 舌側へのたな状の骨添加がみられ る

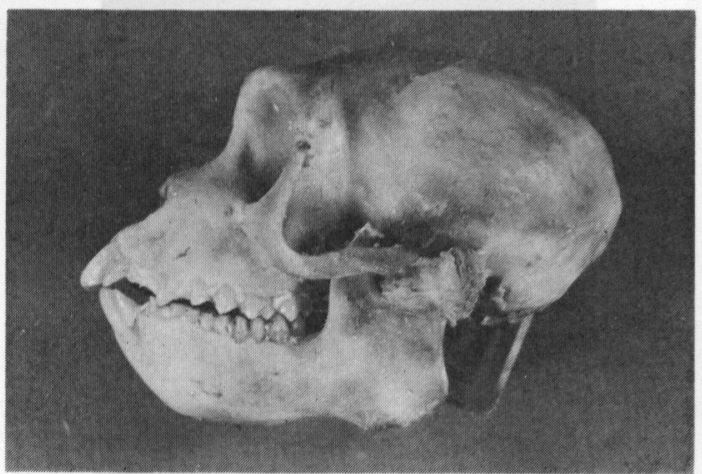

図 $15 \mathrm{U}-\mathrm{TMJ}$ 群実験側 肉眼所見 B-TMJ 群と類似した側面像を示守。

こえた伸長，下顎頭の成長停止，下顎枝角の鋭角度化お よび antegonial notch の強調といった, B-TMJ 群と 同様な変化がみられた。 また，上顎部でも，実験側では 煩骨弓が平坦化し, 非実験側（図16）に比べ著しい垂直 方向への劣成長がみられ, 上下顎とも実験側が著しく矮 小となった（図17）.

b) 計测值

B-TMJ 群（表 1)

B-TMJ 群の計測項目 $1 \sim 3$ は, 正中部であり, B-TMJ 群は $\mathrm{n}=6, \mathrm{C}-\mathrm{TMJ}$ 群は $\mathrm{n}=4$, 計測項目 $4 \sim 17$ は, 1 


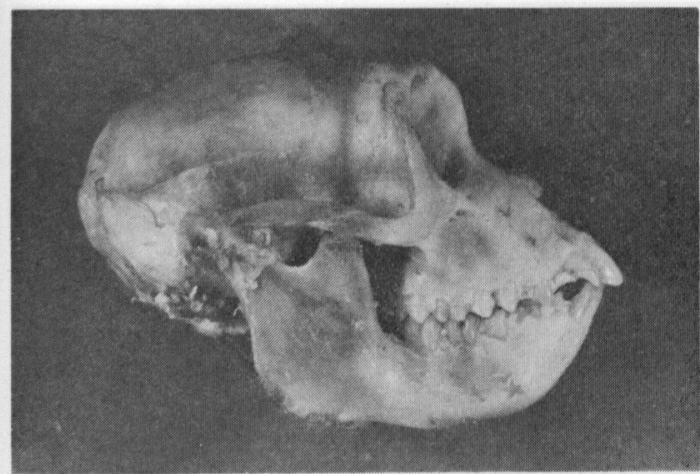

図 16 U-TMJ 群非実験侧 肉眼所見 C-TMJ 群と類似した側面像を示す。

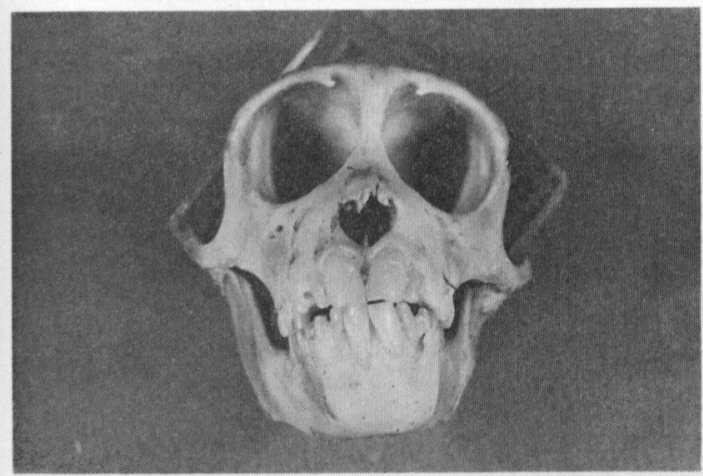

図 17 U-TMJ 群正面像 肉眼所見

実験側（左側）の矮小化がみられる。

匹の動物の左右を数学, B-TMJ 群は $\mathrm{n}=12, \mathrm{C}-\mathrm{TMJ}$ 群 は $\mathrm{n}=8$ いずれも C-TMJ 群を control として比較し た。

下顎骨の計測では，下顎長，下顎枝垂直高および下顎 枝高では, B-TMJ 群の劣成長が有意の差をもってみら

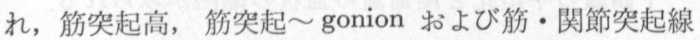
の傾斜角では逆に有意の差をもって B-TMJ 群の過成 長がみられた。また，有意の差はなかったが，B-TMJ 群のほうが，下顎枝角は鋭角度であった。 下顎体長, オ トガイ高, 下顎体高(オトガイ孔部)，下顎体高 $\left(\mathrm{M}_{1}\right.$ 部) および下顎最小枝幅は，両群とも差は認められなかっ た.

すなわち，B-TMJ 群は，下顎枝部において下顎頭の 水平, 垂直両方向への劣成長, 逆に筋突起の過成長拉よ び下顎枝角の鋭角度化といった変化はみられたが，下顎 体部では, 水平, 垂直いずれの方向にも成長量の変化は みられなかった。

上顎部では, 顔面高, 上顔面高, 眼窩下縁〜 上顎歯頸 部, 眼窩下縁〜下顎下縁, 頓骨弓上縁〜下顎下縁, いず れも有意の差をもって B-TMJ 群の劣成長がみられ, 下
表 1 計測結果

\begin{tabular}{|c|c|c|c|c|c|c|c|}
\hline \multirow{2}{*}{ No. } & \multicolumn{3}{|c|}{ B-TMJ 群 } & \multicolumn{3}{|c|}{ C-TMJ 群 } & \multirow{2}{*}{$\mathrm{t}$} \\
\hline & $\mathrm{n}$ & mean & sd & $\mathrm{n}$ & mean & sd & \\
\hline 1 & 6 & 92.3 & 4. 33 & 4 & 100.4 & 4.83 & 0 \\
\hline 2 & 6 & 60.9 & 4. 60 & 4 & 70.0 & 3.52 & 0 \\
\hline 3 & 6 & 37.0 & 2. 65 & 4 & 37.5 & 1.56 & \\
\hline 4 & 12 & 30.4 & 3.33 & 8 & 34.6 & 2.38 & 0 \\
\hline 5 & 12 & 68.6 & 1. 51 & 8 & 71.0 & 0.87 & 0 \\
\hline 6 & 12 & 46.7 & 5. 50 & 8 & 54.8 & 4. 45 & 0 \\
\hline 7 & 12 & 114.3 & 3.10 & 8 & 119.5 & 2.59 & 0 \\
\hline 8. & 12 & 100.1 & 0.96 & 8 & 99.9 & 0.66 & \\
\hline 9 & 12 & 108.4 & 5. 98 & 8 & 112.9 & 4. 02 & \\
\hline 10 & 12 & 27.9 & 2.67 & 8 & 28.5 & 2.17 & \\
\hline 11 & 12 & 26.8 & 2.08 & 8 & 25.6 & 2.60 & \\
\hline 12 & 12 & 41.9 & 3.88 & 8 & 47.5 & 2. 82 & 0 \\
\hline 13 & 12 & 62.1 & 4. 13 & 8 & 58.0 & 2.22 & - \\
\hline 14 & 12 & 45.2 & 3. 70 & 8 & 54.0 & 3. 41 & 0 \\
\hline 15 & 12 & 61.8 & 2. 81 & 8 & 58.1 & 1. 72 & - \\
\hline 16 & 12 & 36.9 & 3.36 & 8 & 34.3 & 2. 23 & \\
\hline 17 & 12 & 117.4 & 6.22 & 8 & 93.0 & 3.70 & $\bullet$ \\
\hline
\end{tabular}

顎頭損傷による成長抑制が下顎骨のみならず，上䫟部に も及んでいるのがみられた。

U-TMJ 群 (表 2)

U-TMJ 群の計測項目 1〜3 3 は, 正中部であるので, C-TMJ 群を control として比較した. U-TMJ 群の左 側 (実験側) の計測項目 $4 \sim 17$ にいては, U-TMJ 群 の右側 (非実験側) を control として比較した，計測項 目 $1 \sim 17$ とも $\mathrm{n}=4$ である。

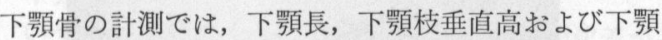
枝高の劣成長, 下䪽枝角の鋭角度化, 筋・関節突起線の 傾斜角の鈍角度化が，実験側に挏いて有意の差をもって みられた。 下顎体長, オトガイ高, 下顎体高（オトガイ 孔部), 下䫇体高 $\left(\mathrm{M}_{1}\right.$ 部), 筋突起高, 笳突起 gonion および下顓最小枝幅には有意の差が認められなかった。

すなわち，U-TMJ 群は，実験側において，下䫇頭部 の水平, 垂直両方向への劣成長, 下顎枝角の鋭角度化が みられたが, 筋突起部, 下顎体部では, 成長量の変化は 認められなかった。

上顎部では，上顔面高，眼窩下縁〜下顎下縁および煩 骨弓上縁〜下頶下縁に扔いて劣成長が有意の差をもって みられ, 顔面高, 眼䆟下縁〜上頢歯頸部も有意の差は認 められないが, 劣成長がみられ, 片側性靧関節損傷の場 合も, 両側性のものよりその程度は少ないが, やはり上 䫇部にも成長抑制が及んでいるのがみられた。 
表 2 計測結果

\begin{tabular}{r|r|r|r|r|r|r|r}
\hline \multirow{2}{*}{ No. } & \multicolumn{3}{|c|}{ U-TMJ 群 } & \multicolumn{3}{|c|}{ C-TMJ 群 } & \multirow{2}{*}{ t } \\
\cline { 2 - 6 } & $\mathrm{n}$ & mean & $\mathrm{sd}$ & $\mathrm{n}$ & mean & $\mathrm{sd}$ & \\
\hline 1 & 4 & 95.6 & 5.10 & 4 & 100.4 & 4.83 & \\
2 & 4 & 62.6 & 3.72 & 4 & 70.0 & 3.52 & 0 \\
3 & 4 & 39.5 & 1.13 & 4 & 37.5 & 1.56 & \\
\hline
\end{tabular}

$\mathrm{p}<0.05 \quad \mathrm{O}-\mathrm{U}-\mathrm{TMJ}$ 群 $<\mathrm{C}-\mathrm{TMJ}$ 群

\begin{tabular}{r|r|r|r|r|r|r|r}
\hline \multicolumn{2}{r|}{} & \multicolumn{2}{|c|}{ U-TMJ 群 ( 1 ) } & \multicolumn{3}{|c|}{ U-TMJ 群 $(\mathrm{r})$} & \\
\hline 4 & 4 & 30.7 & 3.99 & 4 & 34.3 & 1.61 & \\
5 & 4 & 65.9 & 3.43 & 4 & 72.0 & 1.57 & 0 \\
6 & 4 & 46.1 & 5.58 & 4 & 57.0 & 6.16 & 0 \\
7 & 4 & 104.8 & 2.56 & 4 & 114.8 & 3.80 & 0 \\
8 & 4 & 100.0 & 0.37 & 4 & 100.4 & 0.99 & \\
9 & 4 & 91.5 & 4.51 & 4 & 110.0 & 4.97 & 0 \\
10 & 4 & 27.7 & 4.61 & 4 & 27.5 & 1.79 & \\
11 & 4 & 26.5 & 3.31 & 4 & 27.0 & 1.43 & \\
12 & 4 & 38.5 & 4.28 & 4 & 47.3 & 4.00 & 0 \\
13 & 4 & 56.4 & 2.90 & 4 & 58.5 & 1.91 & \\
14 & 4 & 40.0 & 3.40 & 4 & 49.0 & 3.75 & 0 \\
15 & 4 & 57.2 & 4.56 & 4 & 56.6 & 3.84 & \\
16 & 4 & 34.7 & 1.28 & 4 & 35.7 & 2.01 & \\
17 & 4 & 130.5 & 7.77 & 4 & 95.0 & 8.16 & $\bullet$ \\
\hline
\end{tabular}

$\mathrm{p}<0.05 \quad \mathrm{O}-(\mathrm{l})<(\mathrm{r}) \quad-(\mathrm{l})>(\mathrm{r})$

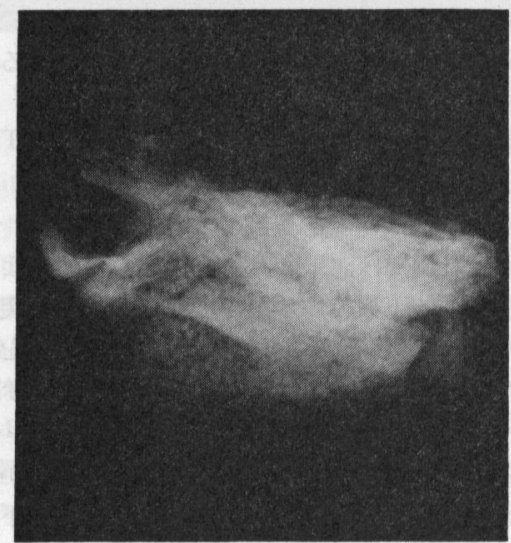

図 18 B-TMJ 群で開口不能となっ た動物 顎関節部X線所見

骨性癒着を疑わしぬる像を示す.

\section{5. 顎関節部のX線的観察}

B-TMJ 群 6 匹中, 開口不能に陥った 2 匹では, 幅広 い関節面を示し，下顎頭と関節窩の境界は消失し，骨性 癒着を疑わしめるX線不透過像がみられた（図 18）。残 りの 4 匹では同じく幅広い関節面を示したが，関節腔隙

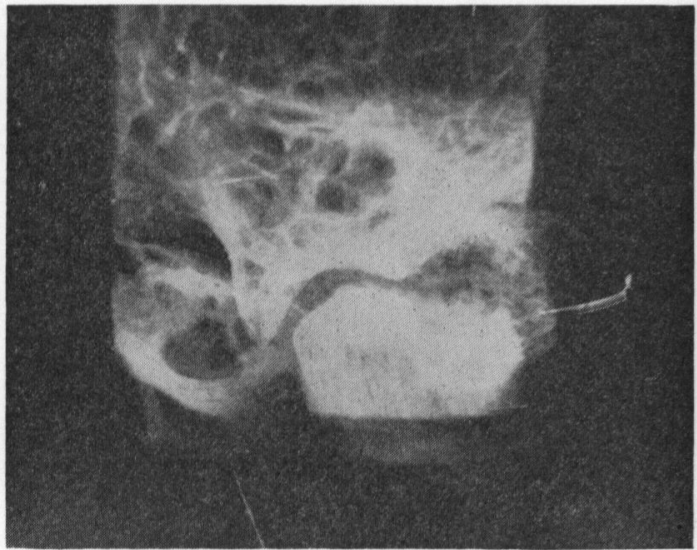

図 19 B-TMJ 群で開口が保たれている動物 顎 関節部X線所見

関節腔隙部の狭小化がみられる。

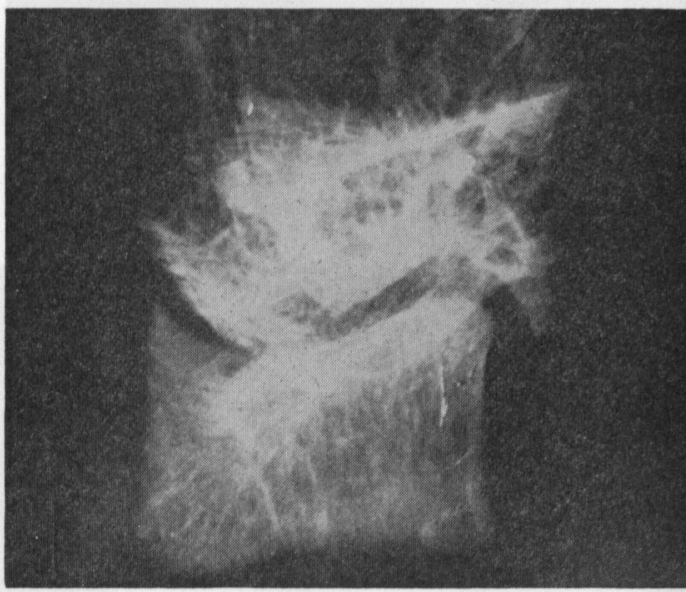

図 20 U-TMJ 群の実験側 顎関節部X線所見 下顎頭の平坦化と関節窩の皿状の陷凹がみられる。

部に相当するX線透過像は狭小化しているが，骨性癒着 を疑わしめる像はなかった（図19）。

U-TMJ 群の実験側（図20）では，下顎頭はやや帯円 形を括びた平坦な幅広い関節面を示し，関節窩はそれに 対応した血状の陥凹を示し，表面は平滑で，骨性痛着 を疑わしめる像はなかった。 U-TMJ 群の非実験側, C-TMJ 群は，いずれも 正常な顎関節像を示した（図 21).
6. TC 生体時刻描記による下顎骨各部の研磨標本の 観察
顎関節部
B-TMJ 群 (図22)，U-TMJ 群の実験側（図 23）で は, TC の沈着はみられず,この部位での成長はみられ 


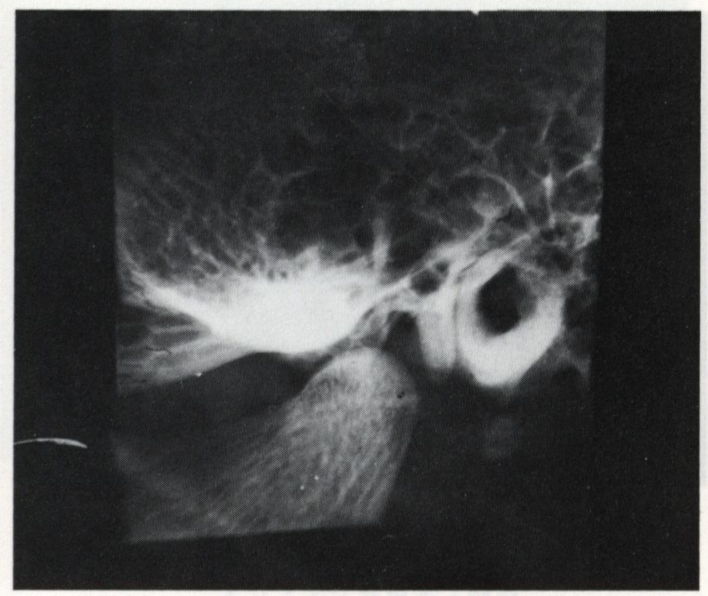

图 21 U-TMJ 群の非実験側 顎関節部X線所見 正常な顎関節像を示す.

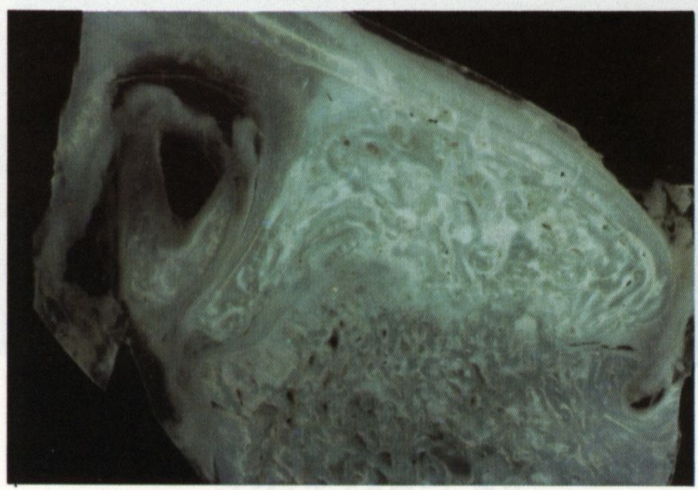

図 22 B-TMJ 群顎関節部 紫外線照射下の螢光 像 $(\times 1.5)$

下顎頭部の成長はみられない。

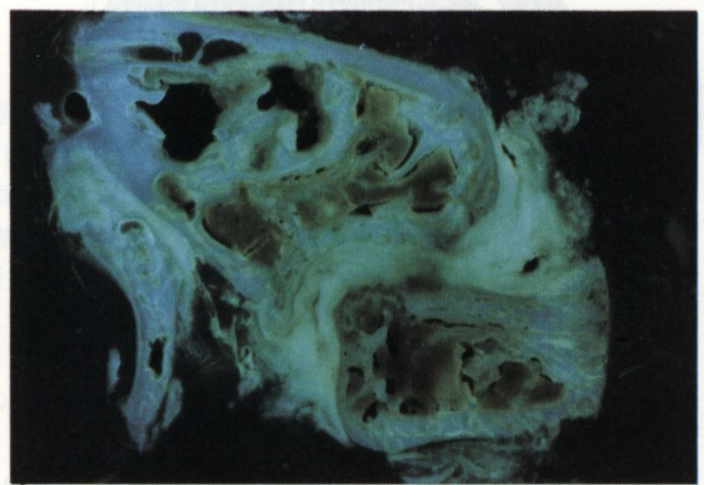

図 23 U-TMJ 群実験側顎阅節部 紫外線照射下 心螢光像 $(\times 1.5)$

下顎䫓部の成長はみられない。

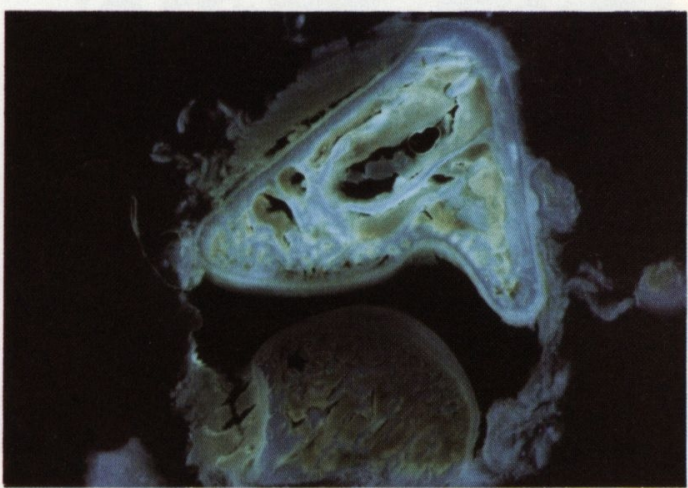

図 24 U-TMJ 群非実験側顎関節部 紫外線照射 下の螢光像 $(\times 1.5)$

下顎頭部の成長がみられる。

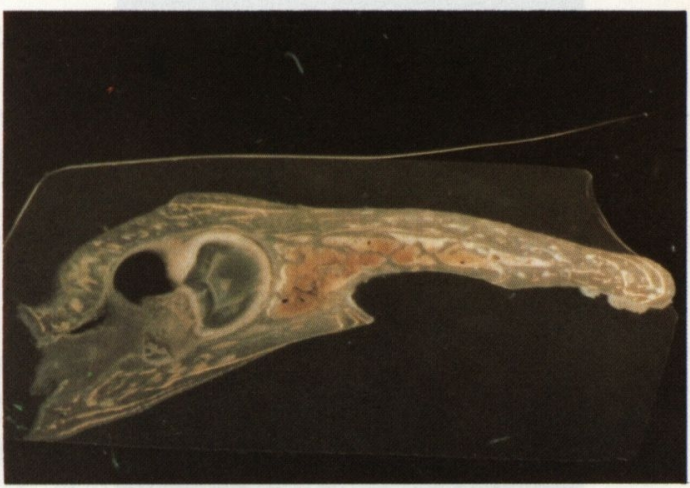

図 25 下顎枝部 紫外線照射下の螢光像 $(\times 1.2)$ 下顎枝後縁の成長がみられる。

なかった、U-TMJ 群の非実験側と C-TMJ 群では, $\mathrm{TC}$ の沈着があり下顎頭の成長がみられた（図24）.

下顎枝部

いずれの実験群とも, 下顎枝後緣の TC の沈着がみ られこの部位での成長がみられた（図25）.

$\overline{6}$ 部

C-TMJ 群, U-TMJ 群および B-TMJ 群で，開口 が保たれている動物では，下顎下緣，煩側および歯槽部 に TC の沈着がみられ, この部位での成長がみられた （図 26）が，B-TMJ 群で開口不能に陥った 2 匹の動物 では，煩側への TC の沈着はみられず，舌側歯慒部と 下顎下縁に TC の沈着がみられ (図27), 開口が保たれ ている動物と成長方向が異なった。 正中部

C-TMJ 群, U-TMJ 群および B-TMJ 群で開口が 保たれている動物では，唇側への TC の沈着，すなわ ち, 唇側への成長がみられた（図28）が, B-TMJ 群で 開口不能に陥った 2 匹の動物では, 唇側への TC の沈 着はなく, 舌側への TC の沈着, すなわち舌側への成 


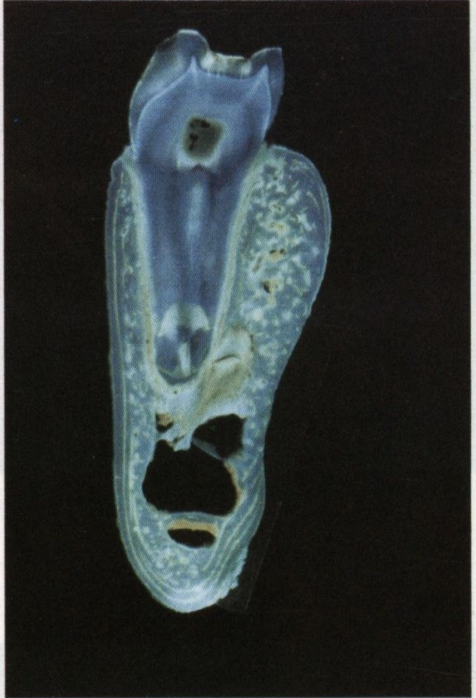

図 26 開口が保たれている動物の第 1 大目米部 紫外線照射下の螢光像 $(\times 1.5)$

下顎下縁，畨槽部，煩側への成長がみられる。

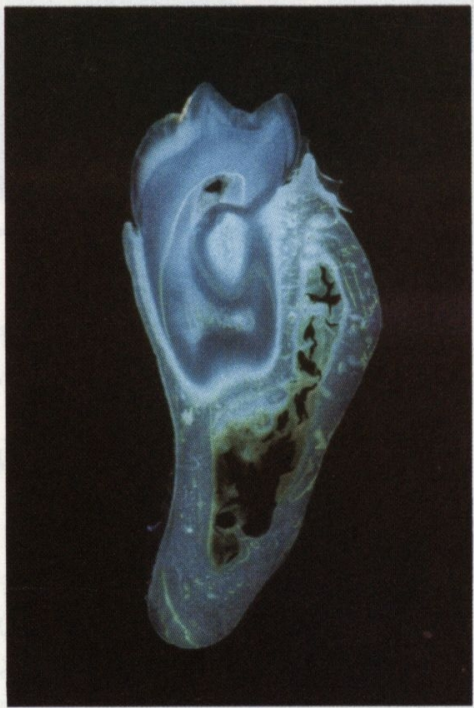

図 27 開口不能となった動物の第 1 大臼歯部 紫外線照射下の螢光像 $(\times 1.5)$

舌側歯槽部と下顎下緣への成長がみられる.

長がみられた（図29）。

\section{7. 蕷関節部の組織学的観察}

B-TM J 群

B-TMJ 群で, 開口不能に陥った 2 匹の動物では, 幅 広い関節面を示し，関節腔隙は完全に消失した。その中 央部では骨性強直像を示し，外側では膠原線維による線

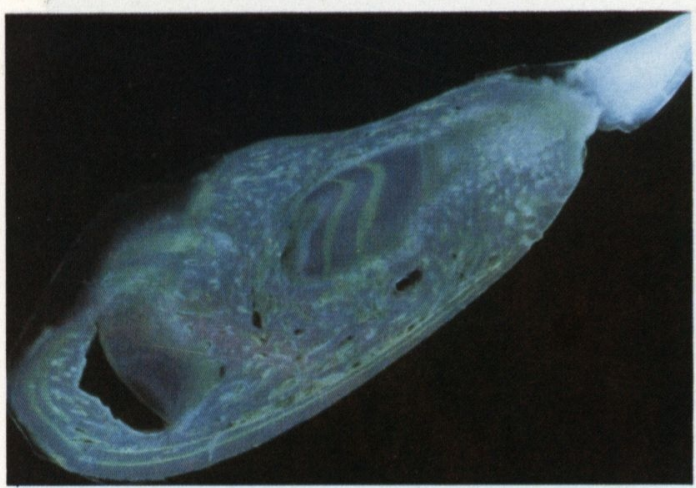

図 28 開口が保たれている動物の正中部 紫外線 照射下の螢光像 $(\times 1.3)$

唇側への成長がみられる。

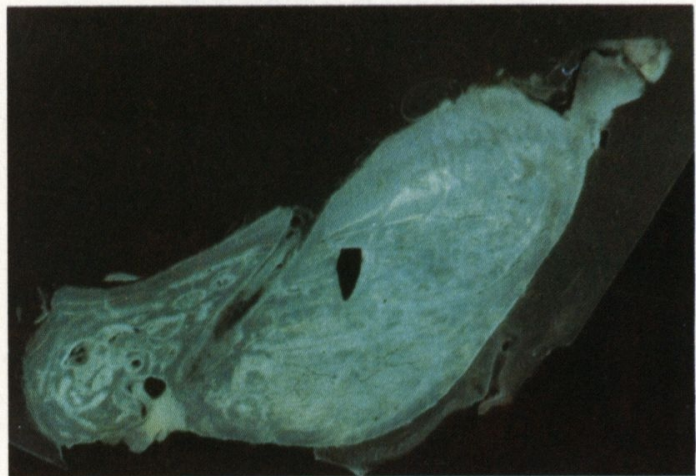

図 29 開口不能となった動物の正中部 紫外線照 射下の螢光像 $(\times 1.3)$

舌側への成長がみられる。

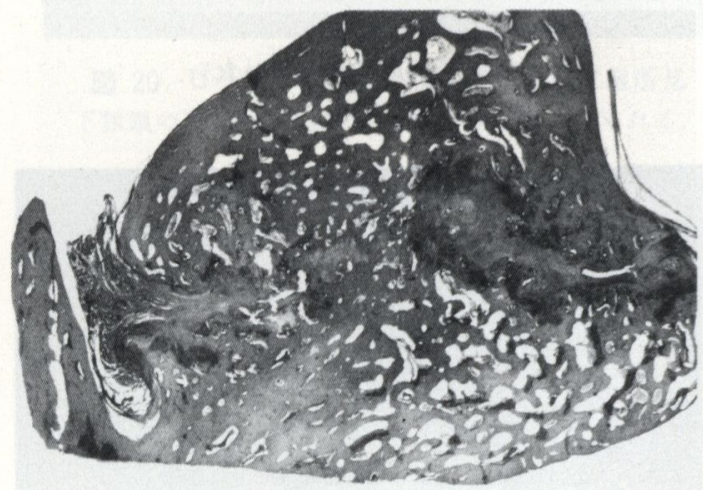

図 30 B-TMJ 群で開口不能となった動物の顎関 節部 H-E 染色 $(\times 1.5)$

骨性強直像を示す。

維性強直像を示した。また，その境界部では硝子様軟骨 や類骨組織がみられた（図 30）。開口が保たれた残りの 4 匹では, 関節腔が狭小化し，しかも膠原線維による線 


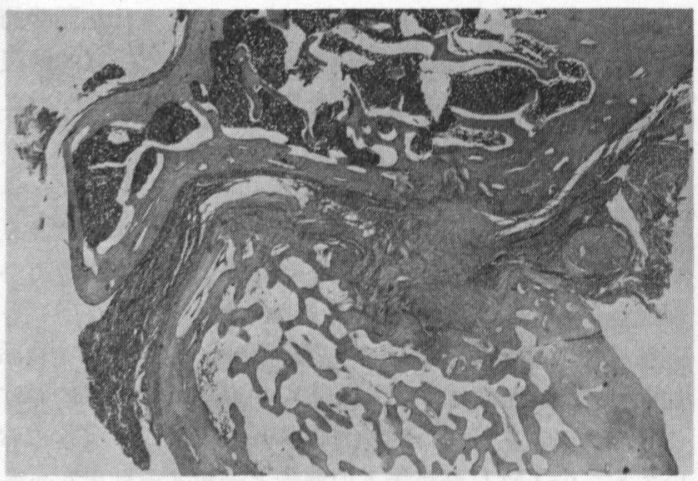

図 31 B-TMJ 群で開口が保たれている動物の筫 関節部 H-E 染色 $(\times 1.5)$

線維性強直像を示す。

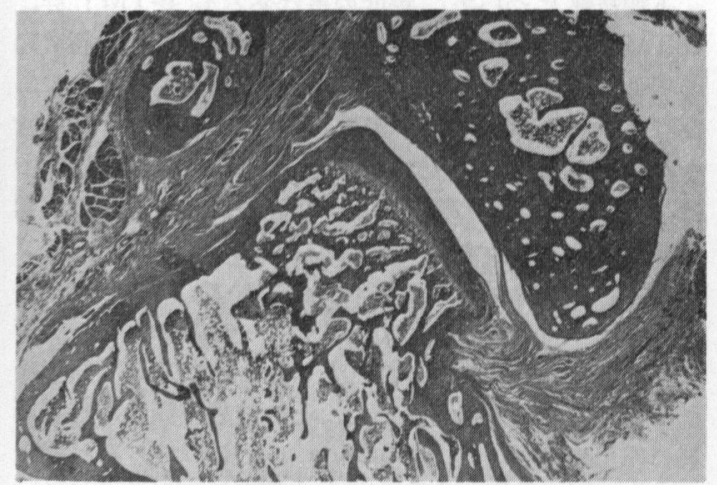

図 32 U-TMJ 群実験側の顎関節部 H-E 染色 ( $\times 1.5)$

関節腔の形成がみられる。

維性強直像を示したが，わずかではあるが膠原線維の中 央に同線維断裂によると思われる空隙がみられ，空隙相 当部の下䫟頭面に，硝子様軟骨の分布がみられた（図 31).

\section{U-TMJ 群の実験側}

下顎頭は平坦ではあるが, やや円みを帯び, 膠原線維 層で被われ，その下に硝子様軟骨層が存在し，関節窩も 下顎頭の形態に一致した平滑な皿状の陥凹を示し，膠原 線維層で被われていた，下顎頭と関節窩を連結する膠原 線維は, 関節の周囲部にはみられたが, 中央部ではみら れず，大きな関節腔が形成されていた（図32）。

U-TMJ 群の非実験側と C-TMJ 群

関節円板, 下顎頭, 関節窩とも正常な組織像を示して いた（図33）。

\section{考} 察

この実験結果から，3つの大きな論点となる考察課題

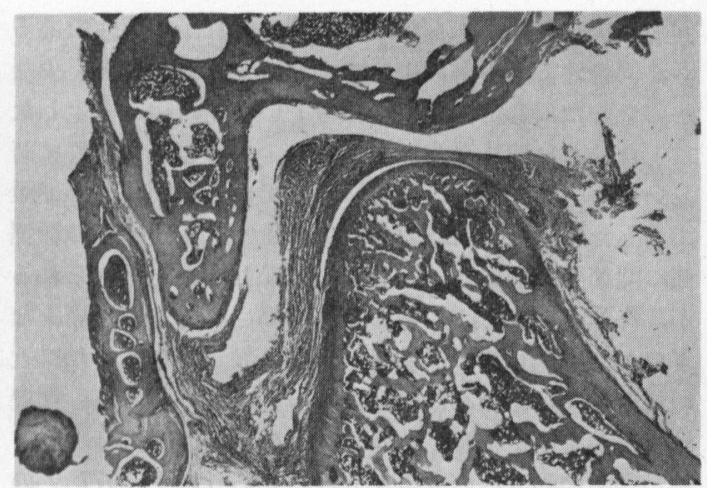

図 33 U-TMJ 群非実験側の顎関節部 H-E 染色 (x1.5)

正常な顎関節像を示す。

が導き出された。

その 1 は, 片側性あるいは両側性に靧関節に損傷が及 んだ場合，顎の機能がどのように変わるかという顎の機 能的変化である.

その 2 は，損傷された顩関節はどのように修復される か，そして修復された㴿関節の下靧頭は再成長するかと いう䫟関節部の変化である.

その 3 は, 㴿関節損傷による顎の機能的变化や顎関節 部の変化により, 顎の成長がどのように変わるかという 靧の成長発育の変化である。 そこで以上の 3 点について 順を追って考察を加える.

\section{1. 䪽の機能的変化について}

U-TMJ 群で, 開口距離が顎関節損傷後, 一時的に減 少し, 約 4 か月で術前值に復し, 以後増大したが, これ は今上 $(1977)^{2)}$ の報告にみられるように, 約 4 か月で， 損傷された顎関節が組織学的に修復されたために開口距 離が術前值に復したものであり，以後の開口距離の増大 は成長に伴うものであると考觉る。また，非実験側への 側方運動が制限されたことは, 組織所見が示すように, 実験側の顎関節の 周囲が厚い膠原線維によって修復さ れ，実験側下㴿頭の前方滑走が抑制されたためであると 考えられ，閉口時の下顎正中の実験側へのずれは，実験 側鿓関節損傷による下䋶頭部の成長停止のための顎の変 位によるものと考兄れる。

B-TMJ 群で, 開口距離が減少し, 側方運動が制限さ れたことは，顎関節強直症の進行を示するのと考える. また実験動物 6 匹中 2 匹が実験開始 1 年経過時に開口不 能に陥ったことは，組織所見にみられる骨性強直がこ の時期には完成されていたものと考觉られ，Allison ら $(1914)^{19)}, \operatorname{Smith}(1950)^{20)}$ が犬の膝関節に外傷を与皇た 実験で, 約 180 日で骨性強直が起こるといら報告と一致 した.

以上のようそ, U-TMJ 群, B-TMJ 群とも顎関節に 
同じ損傷を与えたにもかかわらず，それが片側性である か，両側性であるかによって，前者では機能障害が少な かったのに対して, 後者では著しい機能障害が発生した ことは非常に興味ある所見である。このように両群に著 しい差が生じたのは, U-TMJ 群では, 非実験側が健康 であったために常に開口運動が保たれ，実験側の顎関 節に関節腔が形成され，顎機能が保たれたと考えられる が, B-TMJ 群では, 両側とも損傷されており, 痛みな どのために開口運動が制限されて, 顎が固定されたに近 い状態にあったために顎関節強直症に陥り, 著しい顎機 能障害が生じたと考えられる。このことは開口訓練の有 無が顎関節強直症の成否を分けるといら今上 $(1977)^{2)}$ の 報告によっても明らかである。したがって，機能面から 考えると，顎関節に損傷が及んだ場合は，早期に十分な 開口訓練を行ら必要があることが示唆された.

また興味ある所見として, B-TMJ 群の動物で, 6 匹 中 4 匹に open bite がみられたことがあげられる.この ことは Mason ら(1974) ${ }^{21)}$, Brady ら(1978) ${ }^{22)}$, Gellin $(1978)^{23)}$ の報告にみられる舌王の影響が考えられる。こ れは実験期間中に, 開口障害に陥った動物が十分な食物 摂取ができないため，それを補ら目的で，舌を前方へ押 しやって食物摂取していたのが観察され，その舌圧が働 いたためであると考える.

\section{2. 顎関節部の変化について}

関節損傷後の組織変化に関する研究は, 阪井 $(1969)^{24)}$, 榊田ら $(1972)^{25)}$, 諸富ら $(1972)^{26)}$, 田中 $(1973)^{27)}$ にみら れ，総括すると，可動性を保っておれば，損傷された関 節面は 6 ～8 か月後, 周囲組織より発達した未分化間葉 細胞より化生した軟骨細胞へと転化するが，可動性が保 たれないと，骨などの他の組織に化生すると述べてい る. 本実験では, B-TMJ 群も U-TMJ 群も同じ方法 で顎関節に損傷を与えたにもかかわらず，B-TMJ 群で は，骨性あるいは線維性強直を示したのに反し，U-TMJ 群の実験側では, 関節腔の形成がみられ, 下顎頭が軟骨 細胞で再生されるといら著しい組織修復の違いがみられ た.このことは, やはり可動性の程度のちがいが大きく 関与していると思われる。すなわち，B-TMJ 群では, 両側性に顎関節の障害があり，そのため開口が困難にな り, その程度の強いものが骨性強直症に陥り, その程度 の弱いものが線維性強直症となったと考える。一方, U-TMJ 群では非実験側の顎関節が健全であり, 常に開 ロが保たれたために，実験側の顎関節は強直症に陥ら ず，関節腔の形成がみられたと考える。

それでは，再生された U-TMJ 群の実験側の下顎頭 は再成長するかといら問題が残るが, 組織所見から下顎 頭が損傷時と同じく平坦であり成長がみられないこと, 下顎頭の軟骨層も薄く, 軟骨内骨化を示す所見がないこ と, 研磨標本より $\mathrm{TC}$ の沈着が下顎頭にみられないこ とから，U-TMJ 群の損傷された下顎頭には再成長がお
こらないことがわかった，以上より，損傷された顎関節 は, 開口が保たれれば強直症に陥らず，一応組織的修復 はみられるが，一度損傷された下顎頭には再成長がおこ らないことが判明した。

\section{3. 成長発育の変化について}

正常な状態での下顎骨の成長発育に関しては, 数多く の研究があり, 総括すると, 下顎頭や筋突起の後上方へ の成長 ${ }^{28 \sim 33)}$, 下顎枝後縁の骨添加と前縁の骨吸収 ${ }^{28 \sim 35)}$, 下顎枝角の 鋭角度化 ${ }^{31,33)}$, 下顎下縁と歯槽部への 骨添 加 ${ }^{28 ~ 34)}$ 打よび猿においては下顎前歯部唇側全域におけ る骨添加がみられる ${ }^{31,33)}$ と報告されている，本実験に拈 いても，C-TMJ 群が先人の報告と一致する結果を示し たが, B-TMJ 群, U-TMJ 群では, 正常な動物と異な った発育様式を示したので, 各群の成長発育の変化につ いて考察を加える.

下顎枝部について，程度の差はあるが B-TMJ 群， U-TMJ 群の実験側共通に, 下顎頭の成長停止, 筇突起 の煩骨弓を越えた伸長，著明な下顎枝角の鋭角度化およ び深い antegonial notch がみられたのは condylectomy を行った下顎骨の変形 $\left.{ }^{3} 9\right)$ と同一の所見であり，臨床で は, EL-Mofty(1977) ${ }^{36)}$ の ankylosis に陥った後の下顎 骨の変化とも一致する所見であった.

筋突起の頓骨弓を越えた伸長について, Sorensen ら $(1975)^{8)}$, Lovasko ら (1978) $)^{9)}$ は, condylectomy を行 った実験で，筋突起が伸びたというよりは，下顎頭切除 により下顎骨の支点が失われ，その結果下顎骨が咀嚼筋 群の作用により上方へ rotation したものであると報告 している. しかし本実験では，下顎頭を損傷させてはい るが，下顎骨の支点がなくなるといらほど，その損傷度 は大きくないので，下顎骨の rotation は考えられず， むしろ下顎頭の成長停止に対して, U-TMJ 群では適度 に, B-TMJ 群では過度に筋突起の伸長がみられたもの であると考える。このことは Lifshitz(1976) ${ }^{37)}$ が，側頭 筋を切断した場合に筋突起の劣成長がみられることよ り，筋突起の伸長には側頭筋の機能が不可欠であると報 告していることからもらかがえる。つまり本実験でも， U-TMJ 群では, 顎の機能が十分に保たれており, その ために筋突起が順調に成長したものと思われる。一方, B-TMJ 群では, 開口障害に陥ったために, 咀嚼運動を 保とうとして強く側頭筋の機能が亢進し，そのために筋 突起が過成長を起こしたものと考える.

下顎枝角の鋭角度化と深い antegonial notch の成因 については，種々の報告がみられる。 condylectomyを 行った央験で, Sarnat ら(1951) ${ }^{3)}(1957)^{4)}$ は，下顎骨 の前下方への成長抑制と下顎枝後緣の骨添加が原因であ ると報告し，久保田 $(1960)^{5)}$ は下顎頭の growth center の破填による成長抑制の結果であるが, 咬筋の機能克進 も否定できないと報告し, Sorensen ら(1975) ${ }^{8)}$ は ramus height の減少のため咀嚼筋に働く力が後方へ移動する 
ためであると報告している.

著者は深い antegonial notch については, 咬筋の機 能六進の影響が大きいと考元る。それは，咬筋切断 5 , 38)

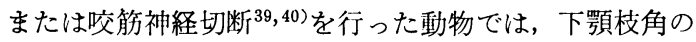
劣成長と antegonial notch の減少がみられたという報 告と，咬筋の発達している人では，下罰枝角は鋭角度化 し, antegonial notch が著明になっているという報告 ${ }^{41)}$ によっても支持される。しかし，下顎枝角の鋭角度化に ついては，咬筋の影響力もあるが， B-TMJ 群の経時的 な頭部X線規格写真にみられるように，むしろ下顎頭部 の成長停止に対して，下顎枝後緣の骨添加が継続した結 果であると考える。

次に，下顎体部について考察する。研磨標本の観察 で，開口が保たれている動物では，第 1 大曰蒾部におい て, 下顎下縁, 煩侧, 幽槽部に向かっての成長, 正中部 において, 唇側向かっての成長がみられ, 正常な成長 発育 $\left.{ }^{31}, 33\right)$ を示したが, 一方, 開口不能となった動物で は, 第 1 大曰歯部に括いて, 下顎下縁, 舌側歯槽部に向 かっての成長, 正中部に执いて, 舌側へ向かっての成長 がみられた。つまり, 開口が保たれている動物, 開口不

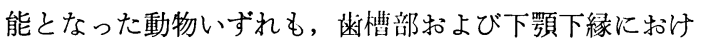
る成長は共通にみられたが，開口不能となった動物で は, 唇, 頓側への成長が抑制され, 舌側への逆成長がみ られた。

このように開口不能となった動物の下顎体部が舌側方 向へ逆成長したのは, 舌侧方向へ牽引する力が強く働い たためであると考えられる。つまり，動物が開口しよう として, 開口筋である素骨上䇨群が収縮しても, 下顎骨 は ankylosis により動かず，そのために，舌骨上筋群の 作用が下顎骨を舌側に牽引するように作用したものであ ると考兄る。この所見は，人の場合には bird face に連 なっていくものと推測される.

次に顎関節損傷による下顎体部の成長抑制の有無を考 える. 計測の結果, B-TMJ 群と U-TMJ 群の実験侧 が, C-TMJ 群と U-TMJ 啡の非実験侧に比べて, 下 䫇長が短いのは, 下顎頭損傷により下顎頭部の後方への 成長が停止したためであると考える。しかし，下靧体長 および下顎体高は, 各群間に差がみられず,特に U-TMJ 群の同一動物の実験側も, 非実験側も,下顎体部の变形 はみられるが，ほぼ同一の計測值を示した。このことか ら，久保田 $(1960)^{5)}$ は下顎頭の損傷により下顎体部にも

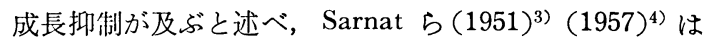
及ばないと述べているが，著者は，下靧体部では下靧頭 の成長停止があっても，下顎体部の変形はみられるが， 成長は継続され，下䫇頭損傷による下罰体部の成長抑制 は起こらないと考える。

以上，下顎骨の変化について述べてきたが， B-TMJ 群, U-TMJ 群の実験侧において, 上罰部にも劣成長と 煩骨弓の平坦化がみられた。 これには， condylectomy
を行った実験で下須枝短縮による影響をあげる報告8) と 変形した下顎骨に対して咬合を保とうとする上顎部の変 形の結果であるといら報告 ${ }^{5)}$ がある。著者は，この実験 結果の理由として, 下頸頭成長停止による下顎枝短縮の ための咬筋をはじめとする咀㗖筋機能の不均衡が，上嘪 部の劣成長に関連していると考兄る. 特に, 頉骨弓の平 坦化は咬筋の機能が充進したためであると考える.

このように，顎関節損傷による顎の成長発育の変位お よび抑制は，下顎頭部の成長停止による変形だけではな く, 顎関節強直症や下靧枝高の減少に伴う罘の機能障害 によって咀嚼筋群の機能の不均衡が生じたためであると 考觉る。

以上の 3 つの考察より, 顎関節に損傷が及んだ場合, 損傷された下顎頭の成長は停止し，下顎枝高は減少し， それに伴い咀嚼筋群の機能の不均衡が起こり, 靧の成長 発育の変位と抑制が起こることが示唆された。 そしてま た, 罘関節強直症に陥れば, 咀嚼筋群の不均衡がさらに 助長され, 顎の成長発育の変位と抑制が強調されること が判明した。

それゆえ，小児期に䫇関節に損傷が及んだ場合は，ま ず積極的な開口訓練を続け，顎関節強直症に陥るのを防 がなければならない．また今後の課題として，小児期に 顎関節が損傷された場合には, growth potential がある といわれる他の組織の下㴿頭への自家移植 ${ }^{22,42)}$ なども検 討し, 下㴿頭部の成長の維持と, 顎の機能を正常に保持 することにより，顎の正常な成長発育を促す必要がある ことが示唆された。

\section{結}

論

幼若な猿の顎関節に, 片側性および両側性に損傷を与 兄, 2 年間飼育し, 顎の機能的変化, 顎関節部の变化沶 よび顎の成長発育の変化を観察し，次の結論を得た．

1. 片側性の 顎関節損傷では, 顎の機能障害は少ない が, 両側性の場合では, 機能障害は大きく, 開口障害が 著しかった。

2. 片側性の頡関節損傷では，損傷靧関節には関節腔 の形成がみられたが，両側性の場合では，線維性あるい は骨性強直症に陥った。

3. 損傷された下顎頭は, その時点から成長は停止し た.

4. 顎関節損傷により，下顎頭の成長の停止，下顎枝 高の減少が起こり, それに伴う咀噞筋群の不均衡による 顎の成長発育の変位と抑制が起こった。 また顎関節強直 症により, 成長発育の変位と抑制はいっそう助長され た。

5. 以上の結果から，小児期の顎関節に損傷が 及んだ 場合は, 顎関節強直症を防ぐ目的で積極的な開口訓練の 必要性が示唆された。 
稿を終えるに際し，懇篤なるご指導ならびにご校閲を いただいた恩師高須淳教授に深甚の謝意を表し, 種々ご 助言いただいた今上茂樹講師に心より感謝するととも に，本研究にご協力下さった教室員各位に謝意を表しま す。また，螢光写真撮影などに関して終始こ配慮，こ援 助いただきました本学小児菌科学教室に厚く打礼申し上 げます。

本論文の要旨は, 第24回日本口腔外科学会総会（昭和 54 年 10 月 4 日, 名古屋市) および第 274 回大阪歯科学会 例会（昭和 54 年 9 月 22 日，大阪市）において発表した。

\section{引用 文 献}

1) Kummoona, R.: Functional rehabilitation of ankylosed temporomandibular joints. Oral Surg 46: 4951978.

2) 今上茂樹：顎関節の機能障害に関する研究 (2. 頡関節損傷後の機能回復と組織修復過程に顎運 動が及ぼす影響に関する実験的研究). 口科誌 26: 4311977 .

3) Sarnat, B.G., et al.: A serial study of mandibular growth after removal of the condyle in the macaca rhesus monkey. Plast Reconstr Surg 7: 3641951.

4) Sarnat, B.G., et al.: Facial and neurocranial growth after removal of the mandibular condyle in the macaca rhesus monkey. Am J Surg 94: 191957.

5）久保田康耶：顎関節侵襲の顔面骨発育に及ぼ す影響に関する実験的研究. 口病誌 $27: 368$ 1960.

6) Choukas, N.C., et al.: Mandibular condylectomy in the rhesus monkey. J Oral Surg 24: 4221966.

7) Sarnat, B.G., et al.: Facial skeletal changes after mandibular condylectomy in the adult monkey. J Anat 108: 3231971.

8) Sorensen, D.C., et al.: Facial growth after condylectomy or ostectomy in the mandibular ramus. J Oral Surg 33: 7461975.

9) Lovasko, J.H., et al.: Facial growth after condylectomy and alloplastic condylar replacement. J Oral Surg 36: 6851978.

10) Bowen, W.H., et al.: Determination of age in monkeys (macaca irus) on the basis of dental development. Laboratory Animals 4: 1131970.

11) Sarnat, B.G.: Surgical experimentation and gross postnatal growth of the face and jaws. J Dent Res 50: 14621971.

12) Martin, R.: Lehrbuch der Anthropologie I. Gustav Fischer Verlag, Stuttgart, 1957, p429.

13）上條雍彦編：口腔解剖学. 第 1 巻, 骨学. 株式 会社アナトーム社, 東京, 1965, 付 1 頁.
14）田中延佳：カニクイザルの下顎骨の成長，歯基 礎誌 17：339 1975.

15）今上茂樹：顎関節の機能障害に関する研究（1. 顎の非可動化が顎関節に及ぼす影锌に関する実 験的研究). 口科誌 26:414 1977.

16）須賀正一編：畨の研究法。医菌薬出版, 東京, 1973，227頁.

17）親里嘉健：妊㐷マウスに投与した oxytetracycline の胎仔透組織への移行に関寸る実験的研 究. 畨科医学 35: 8691972.

18) Morse, A.: Formic acid-sodium citrate decalcification and butyl alcohol dehydration of teeth and bones for sectioning in paraffin. J D Res 24: 1431945.

19) Allison, N., et al.: Ankylosis: An experimental study. Surg Gynec \& Obst 19: 568 1914.

20) Smith, J.B.: Temporomandibular ankylosis. J Oral Surg 8: 2971950.

21) Mason, R.M., et al.: The tongue thrust controversy: background and recommendations. J Speech Hear Disord 39: 1151974.

22) Brady, F.A., et al.: Traumatic ankylosis of the temporomandibular joint. Clin Otolaryng 3: 1271978.

23) Gellin, M.E.: Digital sucking and tongue thrusting in children. Dent Clin North Am 22: 6031978.

24) 阪井 隆 : 関節内骨折の実験的研究. 京府医大 誌 78: 4191969.

25）榊田喜三郎，他：関節軟骨損甥の修復過程に関 する研究。整形外科 23：175 1972.

26）諸富武文，他：幼若結合織(未分化間葉系細胞) の分化について, ${ }^{3} \mathrm{H}$-thymidine autoradiographyによる関節軟骨の修復に関する研究. 臨床 整形外科 7: 3321972 .

27）田中晴人：拘縮が関節軟骨再生に扰よぼす影響 に関する実験的研究。骨代謝 7:75 1973.

28) Robinson, I.B., et al.: Growth pattern of the pig mandible(a serial roentgenographic study using metallic implants). Am J Anat 96: 37 1955.

29) Moss, M.L.: Functional analysis of human mandibular growth. J Pros Dent 10: 1149 1960.

30) Enlow, D.H., et al.: A study of the postnatal growth of the human mandible. Am J Orthodont 50: 251964.

31) Enlow, D.H.: A comparative study of facial growth in homo and macaca. Am J Phys Anthrop 24: 2931966.

32) Enlow, D.H.: The human face: An account of the postnatal growth and development of the craniofacial skeleton. Harper \& Row Publishers, New York, 1968, p 109. 
33) Enlow, D.H.: Handbook of facial growth. W.B. Saunders Company, Philadelphia, 1975, p 241.

34) Scott, E.J., et al.: An experimental study in growth of the mandible. Am J Orthod and Oral Surg 24: 9251938.

35) Mcnamara, J.A., Jr., et al.: Mandibular growth in the rhesus monkey (macaca mulatta). Am J Phys Anthrop 42: 151975.

36) EL-Mofty, S.: Cephalometric studies of patients with ankylosis of the temporomandibular joint. Oral Surg 44: 1531977.

37) Lifshitz, J.: Comparative anatomic study of mandibular growth in rats after bilateral resections of superficial masseter, posterior temporal, and anterior digastric muscles. J Dent Res 55: 8541976.
38) Madeira, M.C., et al.: Splite-line patterns of the mandible following masseterectomy in adult and growing monkeys. Am J Phys Anthrop 47: 411977.

39) Meyerowitz, C., et al: The effect of the masseter muscle on the growing rat mandibule. Diastema 4: 251974.

40）菊池 哲：ラットの咬筇神経切断による下顎骨 発育へ及ぼす影響について。㐘科学報 77：595 1977.

41) Ahlgren, J., et al.: Bruxism and hypertrophy of the masseter muscle (A clinical, morphological and functional investigation). Pract oto-rhino-laryng 31: 221969.

42) Poswillo, D.: Experimental reconstruction of the mandibular joint. Int J Oral Surg 3: 400 1974. 